\title{
Effect of Deformation Conditions on Microstructure and Mechanical Properties of Low All- oyed Steel
}

Ludmila Kučerová ${ }^{1}$, Martin Bystrianský1, Štěpán Jeníček ${ }^{1}$, Pavel Francisko ${ }^{2}$

${ }^{1}$ Regional Technological Institute, Faculty of Mechanical Engineering, UWB in Pilsen. Univerzitni 8, 30614 Pilsen, Czech Republic.E-mail: skal@rti.zcu.cz, mbyst@rti.zcu.cz, jeniceks@vctt.zcu.cz

${ }^{2}$ Expert work in manufacturing and economy, Purkyňova 525/356 01 Sokolov, Czech Republic. E-mail: pa.fr@centrum.cz

Low carbon, low alloyed steel $0.2 \% \mathrm{C}-1.8 \% \mathrm{Si}-1.5 \% \mathrm{Mn}-0.06 \% \mathrm{Nb}$ underwent thermo-mechanical processing routes typical for TRIP (transformation induced plasticity) steels. Deformation conditions were varied, i.e. various numbers of deformation steps of the same size were applied to the steel during the cooling at $50{ }^{\circ} \mathrm{C} / \mathrm{s}$ to room temperature. This processing enabled comparison of recrystallization ability of the steel at various deformation temperatures. In the next step, two $10 \%$ deformations were carried out at the temperatures of $900{ }^{\circ} \mathrm{C}$ and $720^{\circ} \mathrm{C}$ and the deformation rate was varied from $0.025 \mathrm{~s}^{-1}$ to $2.5 \mathrm{~s}^{-1}$ to evaluate the effect of deformation rate on the final microstructure and properties of TRIP steel. In this case, tow-step thermo-mechanical treatment was used with additional $600 \mathrm{~s}$ hold at a coiling temperature of $425^{\circ} \mathrm{C}$. Final microstructures were analysed by light and scanning electron microscopy and mechanical properties were measured by tensile test of small samples. Ultimate tensile strengths in the region of $800 \mathrm{MPa}-1050 \mathrm{MPa}$ were achieved with accompanying total elongation of 5-37\%.

Keywords: TRIP steel, thermo-mechanical treatment, recrystallization

\section{Acknowledgements}

This contribution has been prepared under project LO1502 'Development of the Regional Technological Institute' under the auspices of the National Sustainability Programme I of the Ministry of Education of the Czech Republic aimed at supporting research, experimental development and innovation.

\section{References}

[1] GRAJCAR, A., KWASNY, W., ZALECKI, W. (2015). Microstructure-property relationships in TRIP aided medium-C bainitic steel with lamellar retained austenite. Materials Science and Technology (United Kingdom), Vol. 31, No. 7, pp. 781-794.

[2] KUČEROVÁ, L., JIRKOVÁ, H., MAŠEK, B. (2014). Archives of Metallurgy and Materials, Vol. 59, No.3, pp. 1189-1192.

[3] KUČEROVÁ, L., JIRKOVÁ, H., KÁŇA, J. (2016). The suitability of 42SiCr steel for Quenching and Partitioning Process. Manufacturing Technology, Vol. 16, No. 5, pp. 984-989.

[4] ZACKAY, V.F., PARKER, E.R., FAHR, D., BUSCH, R. (1967). Trans. ASM., Vol.6, pp. 252-259.

[5] VOREL, I., JENÍČEK, Š., KÁŇA, J., IBRAHIM, K., KOTĚSOVEC, V. (2016). Use of Optical and Electron Microscopy in Evaluating Optimization by Material-Technological Modelling of Manufacturing Processes Involving Cooling of Forgings. Manufacturing Technology, Vol. 16, No. 6, pp. 1383-1387.

[6] GRAJCAR, A., RÓZAŃSKI, M., KAMIŃSKA, M., GRZEGORCZYK, B. (2014). Study on non-metallic inclusions in laser-welded trip-aided Nb-microalloyed steel. Archives of Metallurgy and Materials, Vol. 59, No. 3, pp. 1163-1169.

[7] KUČEROVÁ, L., JIRKOVÁ, H., MAŠEK, B. (2016). Influence of Nb Micro-alloying on TRIP Steels Treated by Continuous Cooling Process. Manufacturing Technology, Vol. 16, No. 1, pp. 145-149.

[8] BHATTACHARYYA, T. et al. (2011). Development and characterization of C-Mn-Al-Si-Nb TRIP aided steel, Mater. Sci. Eng. A. Vol. 528, pp. 2394-2400.

[9] BARCELLONA, A., CANNIZZARO, L., PALMERI D. (2007). Microstructural Characterization of Thermo-Mechanical Treated TRIP Steels, Key Engineering Materials, Vol. 344, pp. 71-78.

[10] DOBRZANSKI, L., BOREK, W., MAZURKIEWICZ, J. (2015). Influence of Thermo-Mechanical Treatments on Structure and Mechanical Properties of High-Mn Steel. Advanced Materials Research; Zurich1127, pp. 113-119.

[11] GÓRKA, J. (2013) Effect of heat treatment on the properties of thermomechanically treated steel. Machines, Technologies, Materials. ISSN 1313-0226. ISSUE 12/2013, pp. 24-27.

[12] JACQUES, P. et al. (2001), ISIJ Int 41, pp. 1068-1074.

[13] PERELOMA, E. V., TIMOKHINA, I.B., HODGSON, P.D. (1999), Materials Science and Engineering A $273-$ 275, pp. 448-452. 